\title{
Analysis on Cross-border E-commerce in China Based on Bibliometrics
}

\author{
Jianhua Liu, Song Pan* and Wei Li \\ School of Management Engineering, Zhengzhou University, Zhengzhou 450001, China \\ 759904606@qq.com
}

Keywords: Cross-border e-commerce, Theoretical research, Bibliometrics

\begin{abstract}
With the vigorous development of e-commerce, cross-border e-commerce has also been a widespread focus. Furthermore, the introduction of cross-border e-commerce favorable policy in 2014 stimulated the upsurge of crossborder e-commerce greatly. As a result, cross-border e-commerce becomes a new source of growth for China's trade development gradually, and making it a hot subject in the domestic academy. On the basis of literature data from CNKI and the metrological analysis tools, this paper analyzes the relevant theoretical research of cross-border e-commerce in China during 2001-2016 from the perspective of bibliometrics. The results show that the theoretical studies on crossborder e-commerce in China has been explosive growth since 2014. However, most of these studies are speculative researches, but few cases and empirical studies. Moreover, there are few high quality research results to guide practice, which indicates that it is necessary for future research to be more targeted and practical.
\end{abstract}

\section{INTRODUCTION}

Cross border e-commerce refers to an international business activity that transaction subjects in different customs areas could complete the transaction, payment, logistics and delivery of goods or information through Ecommerce platform (Mengmeng Xu, 2016). Since the outbreak of the US financial crisis in 2008, the economic growth of the world is facing many difficulties. The aggravating trade protectionism, the appreciation of the renminbi, rising raw material prices and labor costs and other unfavorable factors led to China's traditional international trade development is facing enormous pressure. Moreover, the scale of foreign trade import and export growth slowed down, a large number of foreign trade-oriented small and medium enterprises have shut down. However, Under this unfavorable international trade environment, China's Cross-border E-commerce trading volume keep growing trend Surprisingly. According to the data from Ministry of Commerce data, China's traditional foreign trade import and export scale compound annual average growth rate is $6.97 \%$ during the period 2008-2014, while the Cross-border Ecommerce is $33.1 \%$ (Libin E, 2016). With the policy of "one belt on road" and the development of mobile Internet, the prospect of Cross-border E-commerce is more broad, and the theoretical research on Cross-border E-commerce is also concerned greatly by scholars.

Section 2 reviews the literature about Bibliometrics and Cross-border E-commerce. Section 3 provides details on our data sources and research setting. Results and analyze are discussed in detail in Section 4. Section 5 presents concluding remarks.

\section{LITERATURE REVIEW}

\subsection{Studies on Bibliometrics}

The quantitative research on the literature can be traced back to the early 20th century. In 1917, COLE F.J. studied the comparative anatomy literature published during 1543-1860 by using quantitative method (COLE F. J., 1917). In 1926, LOTKA A.J. finds the quantitative relationship of "Inverse Square" from the scientific literature and the paper. And then, e put forward "Lotka Law", which laying a foundation for the birth of bibliometrics (Lotka A. J., 1926). On the basis of the statistic and analysis on the references of some chemical journals papers, GROSSP L.K. obtained the core journals of chemical education (GrossP L.K., 1927). In 1934, after lots of statistical research work, the famous British philologist Bradford S.C. found that different paper of different journals turn out the same distribution law in the corresponding journals, that is N1:N2:N3 =1:n:n2(Bradford Law) (Bradford S. C., 1934). In 1955, Garfield E. proposed a new method of using citation index to retrieve scientific literature which opened the door of a new field that research literature and scientific development from the perspective of citation (Garfield E., 1955). British famous journalist Alan Pritchard first proposed that replace the name of the "statistical catalog" with the term "Bibliometrics" in 1969 (Junping Qiu, 1988). The emergence of this term marks the formal birth of Bibliometrics. In 1973, Small H. defined the "cocitation", and noted that the co-citation network could analyze a particular scientific discipline (Small H., 1973). SEGLEN P.O. described the limitations of influencing factors (IF) in the study of scientific research evaluation, and analyzed the reasons why the IF can not be used to evaluate the study (Seglen P. O., 1997). HIRSCH J.E. first proposed an index to quantify individual research output - the $\mathrm{H}$ index, and gave the calculation method of the index (Hirsch J. E., 2005).

\subsection{Studies on Cross-border E-commerce}

China's Cross-border E-commerce started late, while its development in recent years has subverted the traditional trade model and become the focus of international attention. With the rapid development of Cross-border E-commerce, the theoretical research on it has attracted the attention of domestic scholars greatly. 
WenjingcFan analyzed the case of the transformation of traditional foreign trade enterprises to Cross-border Ecommerce, and the result shows that China's traditional foreign trade enterprises are gradually entering the field of Cross-border E-commerce (Wenjing Fan, 2015). Based on two market theories, Lin Wang, Jianzheng Yang and Shi Yin established an integrated e-commerce performance evaluation model from five dimensions: laws and regulations, technology application, crossborder payment, electronic customs clearance and crossborder logistics (Lin Wang, 2016). Kuojiang Zhu and Lei Zhou analyzed the problems of homogeneity of market positioning of cross-border e-commerce in China, and put forward suggestions on the two levels of government and enterprise (Kuojiang Zhu, 2016). Zhizhong Chen and Luyao Jin analyzed the marketing effect of virus marketing, discussed the virus marketing strategy of Cross-border E-commerce, and put forward some recommendations from the target positioning, release timing, large data utilization and other aspects (Zhizhong Chen, 2016).

This paper uses the method of bibliometrics to analyzed the journal articles in the field of Cross-border E-commerce in China, and summarized the current study situation to provide reference for the follow-up study.

\section{DATA SOURCES AND DATA PROCESSING}

All the literature data in this paper are derived from CNKI (China National Knowledge Infrastructure). CNKI is currently the largest continuous dynamic update of the Chinese journal full-text database over the world that contains more than 8200 kinds of important national journals that including academic, technical, policy guidance, higher science and education. Meanwhile, CNKI also include some journal of fundamental education, public science popularization, public culture, and artistic work. The total amount of documents in CNKI is more than 22 million and the the content of these documents covers many fields including natural science, engineering technology, agriculture, philosophy, medicine, humanities and social sciences, which meets the needs of scientific research and teaching in schools.

According to the research topic, this paper use CNKI's advanced search and set retrieval strategy as "theme = "Cross-border E-commerce", "periodical period = 2001-2016", "source category = all journals". The retrieval date is October 3, 2017. Then, searching the results manually and eliminated the reports, meetings, messages and non authors' documents in the data, obtained 2040 effective journals that regarded as research samples in this paper. It is targeted to use CNKI to retrieve, so the literature data is representative and reliability.

By using CNKI's own metrological analysis tools and EXCEL software, this paper analyzed the 2040 literature samples from the perspective of literature age distribution, research topics (keywords), discipline distribution and the distribution of core journals.

\section{RESULTS AND ANALYSIS}

\subsection{Trends in Literature Research}

This paper summarized 2040 literature about Crossborder E-commerce during 2001-2016 according to the time distribution, see Figure 1. According to the trend shown in Figure 1, this paper divides the theoretical research of domestic Cross-border E-commerce into three stages.The first stage is 2001-2011. There are few literature at this stage, and the number of literature per year is in single digits. This period is the initial stage of Cross-border E-commerce theory research. In addition, the number of literature during 2004-2006 is zero, which may be due to the fact that "SARS" has seriously affected the academic research of Cross-border Ecommerce at this stage. The second stage is 2012-2013. At this stage, the domestic literature on Cross-border Ecommerce shows a relatively large growth. The third stage is 2014-2016. At this stage, the number of literature on Cross-border E-commerce showed explosive growth, and the total number of literature reached 1966 which accounting for $75 \%$ of the total literature. It is worth mentioning that the China General Administration of Customs in July 2014 introduced the policy of "cross-border trade on e-commerce inbound and outbound goods, articles on the supervision of the notice" and "on the additional customs supervision mode code announcement" that recognize the Cross-border Ecommerce and the industry's bonded model from the policy level, which greatly stimulated the development of Cross-border E-commerce, and the academic research on Cross-border E-commerce is also sprung up.

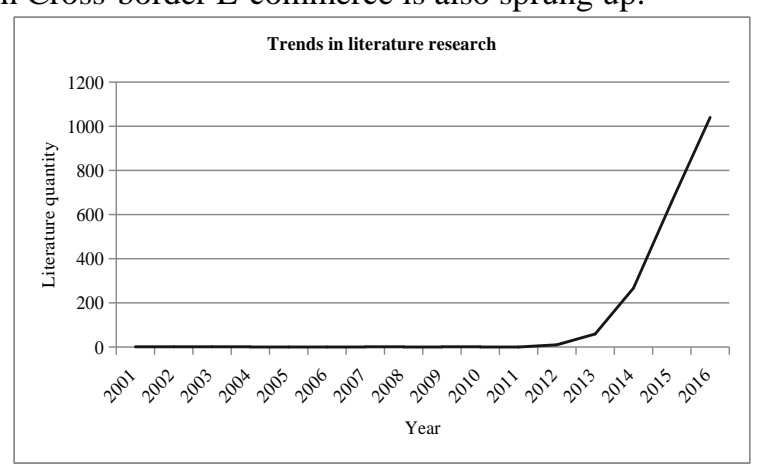

Figure 1: Trends in literature research in 2001-2016

\subsection{Research Topics (Keywords)}

The key words of the scientific papers can reflect the research topics and concerns of the research papers, and the high-frequency vocabulary analysis in a research topic of a research topic can well reflect the focus and development trend of the field (Xiangxu Yin, 2009). The higher the frequency of keyword occurrence, the greater the degree of concern to the scholars, that is, the hotspot of research. Table 1 lists the changes and frequency of keywords in three different stages of the 2001-2006 domestic Cross-border E-commerce research paper. Table 1 shows that "Cross-border E-commerce", "Crossborder Online retailers" and "E-commerce" in three stages has always been a high-frequency word in the field of Cross-border E-commerce. During 2001-2011, the relevant literature research is in the early stage, and 
the research content mainly related to the rise, profit model, and consumers of Cross-border E-commerce. In 2012-2013, the studies turned to foreign exchange management, cross-border logistics, Cross-border Ecommerce development strategies. The research began to refine and deepen. It is significant increases in research

Table 1: The high frequency keywords of literature on Cross-border E-commerce in China during 2001-2016 (Top 10)

\begin{tabular}{|c|c|c|c|c|c|}
\hline \multicolumn{2}{|c|}{$2001-2011$} & \multicolumn{2}{|c|}{$2012-2013$} & \multicolumn{2}{|c|}{$2014-2016$} \\
\hline Keywords & frequency & Keywords & frequency & Keywords & frequency \\
\hline E-commerce & 4 & $\begin{array}{c}\text { Cross-border E- } \\
\text { commerce }\end{array}$ & 9 & $\begin{array}{c}\text { Cross-border E- } \\
\text { commerce }\end{array}$ & 683 \\
\hline $\begin{array}{c}\text { Cross-border E- } \\
\text { commerce }\end{array}$ & 3 & E-commerce & 7 & $\begin{array}{c}\text { Cross-border } \\
\text { Online retailers }\end{array}$ & 309 \\
\hline $\begin{array}{l}\text { Third party } \\
\text { payment }\end{array}$ & 1 & $\begin{array}{c}\text { Foreign } \\
\text { exchange }\end{array}$ & 3 & E-commerce & 164 \\
\hline Profit model & 1 & $\begin{array}{l}\text { Cross-border } \\
\text { logistics }\end{array}$ & 2 & Countermeasure & 72 \\
\hline Consumer & 1 & $\begin{array}{l}\text { Third party } \\
\text { payment }\end{array}$ & 2 & Cross-border & 64 \\
\hline Problem & 1 & Small amount & 2 & $\begin{array}{c}\text { Talent } \\
\text { development }\end{array}$ & 62 \\
\hline Internet & 1 & Cross-border & 2 & Logistics & 60 \\
\hline International & 1 & $\begin{array}{l}\text { Third party } \\
\text { payment } \\
\text { institution }\end{array}$ & 2 & $\begin{array}{l}\text { International } \\
\text { trade }\end{array}$ & 49 \\
\hline $\begin{array}{c}\text { Special } \\
\text { regulatory area }\end{array}$ & 1 & Countermeasure & 2 & $\begin{array}{c}\text { Cross-border } \\
\text { logistics }\end{array}$ & 47 \\
\hline rise & 1 & Development & 2 & Problem & 34 \\
\hline Small amount & 1 & $\begin{array}{c}\text { Exchange } \\
\text { management }\end{array}$ & 2 & Development & 31 \\
\hline Countermeasure & 1 & $\begin{array}{c}\text { Cross-border } \\
\text { logistics }\end{array}$ & 2 & Internet+ & 29 \\
\hline
\end{tabular}

\subsection{Discipline Distribution}

Table 2 lists the Discipline distribution of domestic Cross-border E-commerce research literature during 2001-2016. It can be seen that the studies on Crossborder E-commerce in China is mainly concentrated in the fields of trade economy, macroeconomic

Table 2: Discipline distribution of domestic Cross - border E - commerce research literature during 2001-2016(Top 12)

\begin{tabular}{|c|c|c|c|c|c|c|}
\hline Discipline & trade economy & $\begin{array}{c}\text { macroeconomic } \\
\text { management } \\
\text { and sustainable } \\
\text { development } \\
\end{array}$ & finance & $\begin{array}{l}\text { vocational } \\
\text { education }\end{array}$ & $\begin{array}{l}\text { economic } \\
\text { system reform }\end{array}$ & $\begin{array}{c}\text { Higher } \\
\text { education }\end{array}$ \\
\hline $\begin{array}{c}\text { Literature } \\
\text { quantity }\end{array}$ & 1793 & 220 & 93 & 92 & 76 & 55 \\
\hline Proportion & $64.50 \%$ & $7.97 \%$ & $.3 .35 \%$ & $3.31 \%$ & $2.73 \%$ & $1.98 \%$ \\
\hline Discipline & $\begin{array}{l}\text { Enterprise } \\
\text { economy }\end{array}$ & $\begin{array}{l}\text { Finance and } \\
\text { taxation }\end{array}$ & $\begin{array}{l}\text { Foreign } \\
\text { language }\end{array}$ & $\begin{array}{l}\text { Industrial } \\
\text { economy }\end{array}$ & $\begin{array}{l}\text { Information } \\
\text { Economy and } \\
\text { Post Economy }\end{array}$ & $\begin{array}{c}\text { Computer } \\
\text { software and } \\
\text { computer } \\
\text { application }\end{array}$ \\
\hline $\begin{array}{c}\text { Literature } \\
\text { quantity }\end{array}$ & 52 & 50 & 49 & 47 & 45 & 30 \\
\hline Proportion & $1.87 \%$ & $1.80 \%$ & $1.76 \%$ & $1.69 \%$ & $1.62 \%$ & $1.08 \%$ \\
\hline
\end{tabular}

\subsection{Core Journal Analysis}

Bradford proposed that order the relevant journals according to the number of paper that included in correspond which can be divided into the core journals and general journals. Fig.2. is the age distribution of the core journals and CSSCI journals about Cross-border Ecommerce in 2001-2016. Table 3 is the distribution of results during 2014-2016. In addition to Continuous study about basic theory in this field, this stage also pay more attention to the development of Cross-border Ecommerce research prospects, including talent development, cross-border logistics and Internet + and other aspects. management and sustainable development, finance, vocational education, economic system reform and enterprise economy. This shows that China's Crossborder E-commerce disciplines are concentrated, and are speculative studies based on the economic and management level basically.

the journals about Cross-border E-commerce in 20012016. There are 99 papers published at the core journals and CSSCI journals, and accounting for $5 \%$ of the total literature; there are just 1 core journal among the top 12 journals listed in Table 3, and no CSSCI journal. It can be seen that although there are many research papers in the field of Cross-border E-commerce, the quality of 
paper is unsatisfactory, and the number of high-level papers included in core journals is too small. This shows that the research level of domestic scholars on the field of cross-border e-commerce is relatively low, and the depth of research needs to be deepened.

Table 3: The distribution of the journals about Crossborder E-commerce during 2001-2016 (Top 12)

\begin{tabular}{|c|c|c|c|}
\hline Order & Journal Title & $\begin{array}{c}\text { Quantity of } \\
\text { published } \\
\text { articles }\end{array}$ & Journal level \\
\hline 1 & $\begin{array}{c}\text { Market } \\
\text { Modernization }\end{array}$ & 69 & $\begin{array}{c}\text { General } \\
\text { journal }\end{array}$ \\
\hline 2 & Modern Business & 59 & $\begin{array}{c}\text { General } \\
\text { journal }\end{array}$ \\
\hline 3 & E-commerce & 57 & $\begin{array}{c}\text { General } \\
\text { journal }\end{array}$ \\
\hline 4 & $\begin{array}{c}\text { China Business \& } \\
\text { Trade }\end{array}$ & 56 & $\begin{array}{c}\text { General } \\
\text { journal }\end{array}$ \\
\hline 5 & $\begin{array}{c}\text { Journal of } \\
\text { Commercial } \\
\text { Economics }\end{array}$ & 42 & $\begin{array}{c}\text { General } \\
\text { journal }\end{array}$ \\
\hline 6 & $\begin{array}{l}\text { Modern Economic } \\
\text { Information }\end{array}$ & 42 & $\begin{array}{c}\text { General } \\
\text { journal }\end{array}$ \\
\hline 7 & Manager’ Journal & 37 & $\begin{array}{c}\text { General } \\
\text { journal }\end{array}$ \\
\hline 8 & Business & 32 & $\begin{array}{c}\text { General } \\
\text { journal }\end{array}$ \\
\hline 9 & China Market & 30 & $\begin{array}{c}\text { General } \\
\text { journal }\end{array}$ \\
\hline 10 & $\begin{array}{c}\text { Practice in Foreign } \\
\text { Economic } \\
\text { Relations and } \\
\text { Trade } \\
\end{array}$ & 27 & Core journal \\
\hline 11 & $\begin{array}{l}\text { Modern Business } \\
\text { Trade Industry }\end{array}$ & 27 & $\begin{array}{l}\text { General } \\
\text { journal }\end{array}$ \\
\hline 12 & $\begin{array}{l}\text { Foreign Economic } \\
\text { Relations \& Trade }\end{array}$ & 26 & $\begin{array}{c}\text { General } \\
\text { journal }\end{array}$ \\
\hline
\end{tabular}

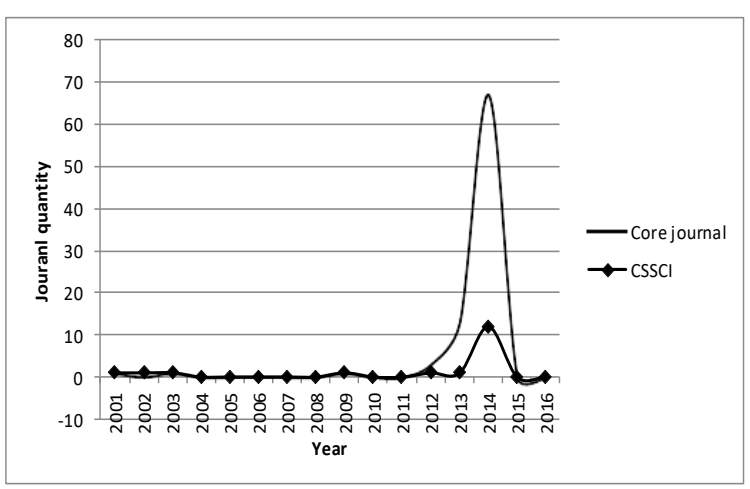

Figure 2: The age distribution of the core journals and CSSCI journals about Cross-border E-commerce in 2001-2016

\section{CONCLUSIONS}

This paper reveals the progress of theoretical research in the field of Cross-border E-commerce in China from 2001 to 2016, which is based on the literature age distribution, research topics (keywords), discipline distribution and the distribution of core journals. And finally obtain some conclusions.

(1) The theoretical research in the field of Crossborder E-commerce in China has shown an explosive growth since 2014, which is in line with the actual situation of China's favorable policies for promoting cross-border electricity development in 2014.

(2) The theoretical research of China's Cross-border E-commerce mainly focused on profit model, development model, development strategies and crossborder logistics and other aspects; these studies are almost speculative research, and few cases and empirical studies; moreover, most studies lack data support.

(3) Although there are many research papers in the field of Cross-border E-commerce, the quality of paper is unsatisfactory.

Nowadays, Cross-border E-commerce is at the peak stage of development, which bring a large theoretical research space. Future theoretical research should be more targeted so as to provide personalized and practical guidance for the actual development of Cross-border Ecommerce.

\section{REFERENCES}

[1] Bradford, S.C., 1934. Sources of information on specific subjects[J]. Engineering, pp.137:85 -86.

[2] COLE, F.J., Hulme, E.W., 1917. The history of comparative anatomy-A statistical analysis of the literature[J] . Science Progress. 1917(11), pp. 578-596.

[3] Garfield, E., 1955. Citation Indexes for Science:A new dimension in documentation through association of ideas[J] . Science. 122 (3159), pp.108-111.

[4] GrossP, L.K., Gross, E.M., 1927. College libraries and chemical education [J]. Science. 66(1713), pp.385-389.

[5] Hirsch, J.E., 2005. An index to quantify an individual's scientific research output[J]. The National Academy of Sciences of the USA. 102(46), pp.16569 -16572.

[6] Junping Qiu, 1988. Bibliometrics[M], Science and Technology Literature Press. Beijing, 2nd edition.

[7] Kuojiang Zhu, Lei Zhou, 2016. Problems and Countermeasures of cross border e-commerce in China based on transaction cost theory[J]. Journal of Commercial Economics. 2016(13), pp.97-99.

[8] Libin, E., Yongwen Huang, 2014. New ways of international trade: the latest research on cross border Ecommerce[J]. J Dongbei Univ Financ Econ. 2014(02), pp.2231.

[9] Lin Wang, Jian Yang, et al., 2016. A Contrastive Study on the Performance of Cross-border E-commerce in Difference Industries[J]. Contemp Econ Manag. 38(4), pp.46-52.

[10] Lotka, A.J., 1926. The frequency distribution of scientific productivity[J]. Journal of the Washington Academy of Sciences. 16(12), pp.317 -323.

[11] Mengmeng Xu, 2016. Research on the status and issues of china's Cross-border E-commerce--based on Alibaab's SWOT analysis[D]. Anhui University.

[12] Seglen, P.O., 1997. Why the impact factor of journals should not be used for evaluating research[J]. BMJ. 314(7079), pp.497 -502.

[13] Small, H., 1973. Co-citation in the scientific literature:A new measure of the relationship between two documents[J]. Journal of the American Society for Information Science and Technology. 24(4), pp.265 -269.

[14] Wenjing Fan, 2015. Cross-border E-commerce development and the transformation of China's foreign trade model[J]. Foreign Economic Relations \& Trade. 2015(01), 
pp.4-7.

[15] Xiangxu Yin, Gengping Zhang, et al., 2009. Analysis of Information Science Research Based on keywords statistics[J]. Journal of Information. 28(11), pp.1-4.

[16] Zhizhong Chen, Luyao Jin, 2016. Analysis of cross-border platform viral marketing strategies[J]. Modern Management Science. 2016(9), pp.33-35. 